\title{
Characteristics of Lactic Acid Bacterium Which are Isolated From Pineapple Pickles, Cucumber and Carrots
}

\author{
Indra Hartanto ${ }^{1 *}$ Resti Fevria ${ }^{1}$ Vauzia ${ }^{2}$ \\ ${ }^{1}$ Dept. of Biology, Faculty of Mathematics and Science (FMIPA), Universitas Negeri Padang, Padang, Indonesia \\ ${ }^{2}$ Dept. of Biology, Faculty of Mathematics and Science (FMIPA), Universitas Negeri Padang, Padang, Indonesia \\ ${ }^{3}$ Dept. of Biology, Faculty of Mathematics and Science (FMIPA), Universitas Negeri Padang, Padang, Indonesia \\ *Corresponding author. Email: indrahartanto.1971@gmail.com
}

\begin{abstract}
Pickles are made from a mixture of chunks of pineapple, cucumber and carrot with addition of 2.5 percent salt, $2.5 \%$ sugar and $2.5 \%$ cayenne papper. Pickles are served as a side dish at restaurants, which serve fried foods or meats such as mutton, soto and fried rice. Besides the unique taste of pickles, a mixture of salty, sweet and spicy, pickles also have benefits for maintaining cholesterol levels in the body. Cholesterol levels in the body can be lowered by Lactic Acid Bacteria. Lactic Acid bacteria, especially the genus Lactobacillus, are part of the normal flora in the human digestive tract, and is a probiotic that can have beneficial effects on health. This research aims to know the characteristics of LAB originated pickles. Tools and materials used consist of pineapple pickles, cucumber and carrots fermentation. LAB isolation from pickles done in fermentation and then plant to specific medium with pour plate method, then identified microscopically. The results obtained from this study were 9 isolate LAB from suerkraut, its caracteristics are negative catalase test. Keywords: pineapple, cucumber, pickles, Lactic Acid Bacteria, Lactobacillus sp.

\section{INTRODUCTION}

Pickles (pikcles) are ways to preserve food using vinegar or brine. The ingredients are, pineapple, cucumber and carrots, chillies, onions and salt. Pickled fish served as a side dish in restaurants serving fried food, meat, soup and fried rice. Besides the unique taste of pickles, a mixture of salty, sweet and spicy, pickles also have benefits for maintaining cholesterol levels in the body. Cholesterol levels in the body can be lowered by Lactic Acid Bacteria. Lactic Acid bacteria, especially the genus Lactobacillus, are part of the normal flora of the human digestive tract,

fermentation in making pickles also improves nutrition and facilitates digestion in the body ${ }^{[1]}$. Lactic acid bacteria, especially the genus Lactobacillus, are part of the normal flora of the human digestive tract. Lactobacillus is a probiotic that can have beneficial effects on health.

At present, lactic acid bacteria have been obtained from several natural ingredients like strawberries ${ }^{[2]}$, yellow passion fruit ${ }^{[3]}$ and unggu passion fruit ${ }^{[4]}$, tomatoes ${ }^{[5]}$. Based on the above, then conducted research Characteristics of Lactic Acid Bacteria which are Isolated from Pineapple Pickles, Cucumber and Carrots.
\end{abstract} and are pr biotics that can have beneficial effects on health Pickles can be made using one or more types of vegetables as the basic ingredients, but the complete nutritional content and high water content in vegetables makes spoilage microbes easily grow and multiply, so vegetables have a short shelf life. One food preservation technique that can extend the shelf life of vegetables is fermentation. The naturally occurring fermentation process is influenced by the main ingredients used in making pickles. Fermentation in pickling is fermented.

Fermentation begins with the growth of Leuconostoc mesenteroides which will condition the environment so that other lactic acid bacteria such as Lactobacilli can grow. Lactic acid bacteria that are very important in traditional pickling production are Lactobacillus plantarum . During fermentation, the growing lactic acid bacteria can convert sugars in ingredients into acids. In addition to producing a unique flavor of pickles,

\section{MATERIALS AND METHODS}

This study has been done at the FMIPA Laboratory department of Biology in Juni - Juli 2019, with the procedure:

\subsection{Materials and Equipment}

This research uses pickled pineapple, cucumber and carrot objects which are bought from the Padang Panjang market. Then the material is fermented with the addition of salt 2,5

$\%, 2.5 \%$ sugar and $2.5 \%$ cayenne pepper, and vinegar. The part that will be examined is the result of pickled fermentation. And the medium used is the Medium de Men Rogrosa Sharpe (MRS) for Marks, $\mathrm{NaCl}, \mathrm{H} 2 \mathrm{O} 2$, Violet Crystal, iodine lugol paint, alcohol and safranin 
from the Biology Laboratory of FMIPA Padang State University.

The tools used in this study are, knife blades, balance scales, test tube, Erlenmeyer, petri, laminar air flow, objects

glass, plates, tweezers, Bunsen, porcelain plates, spells, scratch plates rack, microscope.

\subsection{Research Implementation}

Sample Preparation (Making pickles) Pickles are made by means of: $1 \mathrm{~kg}$ of cucumber washed, then diced, 2 carrots, peeled, washed, diced, 3 sliced cayenne peppers, $2.5 \%$ granulated sugar, $50 \mathrm{ml}$ vinegar, $2.5 \%$ salt, re-fermentation at $37{ }^{\circ} \mathrm{C}$ for 3 days. The pickled fermentation results were then analyzed.

\subsection{Samples}

The sample is made by cutting ingredients like dice that add 2,5\% salt, 2,5\% sugar. Ater that it is put into a bottle and tightly closed. Fermentation for 36 hours, for isolation take the liquid and grow it to a specific medium and make microscopic and macroscopic observations. Isolated until a single isolate or colony is obtained from each petri dish.

\subsection{Identification}

Macroscopic identification is carried out with the observation of the colony's form, the color of the colony and the surface form of the colony while the microscopic identification is done by shaking the bacteria into the glued object and slash the violet crystals for one minute, washing and drain with water, the iodine is one minute, wash and drain with water, decolorization with alcohol for 30 second, wash and drain again, drop a safranir 30 second, observe under the microscope.

\subsection{Catalase Test}

Catalase test is a test of certain bacteria whether the bacteria are aerobic bacteria, facultative anaerobes, or facultative anaerobes, the way is 1) take bacterial culture. 2) Drop one drop of $\mathrm{H} 2 \mathrm{O} 2$ into bacterial culture 3) Observe until there is a bubble or not

\section{RESULT AND DISCUSSION \\ 3.1. Result}

Isolation is done by pour plate method with MRSA media containing $1 \% \mathrm{CaCO}$. Colonies that appear and form clear zones. These bacteria which are large and form a single colony as shown in the picture are bacteria taken for testing. Single bacterial colonies that form clear zones are counted using a colony counter. Calculation results obtained as many as 17 colonies isolate.

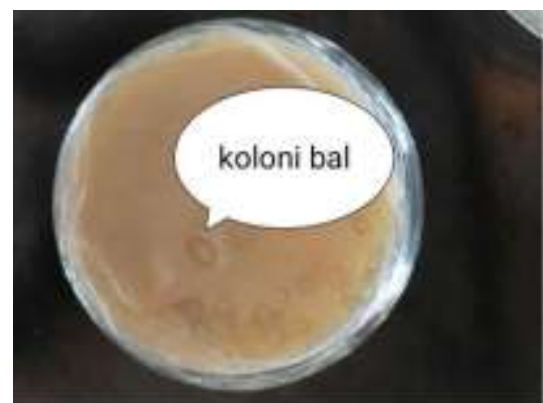

Figure 1. Isolation observation from Pickles 36 hours from dilution of 106 on medium

Based on the picture above lactic acid bacteria that can be isolated 17 colonies. Lactic acid bacteria are isolated to produce antimicrobials that can be used as probiotics. Lactic acid bacteria produce antibacterial in the form of organic acids, bacteriocins, primary metabolites, hydrogen peroxide, diacyl, carbon dioxide, acetaldehyde and reduce the $\mathrm{pH}$ of the environment by expressing compounds that can inhibit pathogenic bacteria ${ }^{[7]}$. Some genera that produce bacteriocin and have great inhibitory activity against the growth of some pathogenic bacteria are Lactobacillus, Lactococcus, Streptococcus, found in the digestive tract ${ }^{[7]}$.

\subsection{Identification of Isolated Isolates}

\subsubsection{Gram staining}

The result of gram-staining under the microscope can be seen in table 1 .

Table 1. Gram dyeing result

\begin{tabular}{|l|l|}
\hline Observations under a microscope & \multicolumn{1}{|c|}{ Result } \\
\hline & Result : Positif \\
\hline & \\
\hline
\end{tabular}

In the gram stain cells can not release the color and will remain-colored crystal violet are blue-ungu called Gram-positive bacteria, $\mathrm{h}$ al is due to these bacteria have a lipid content lower, so that the bacterial cell wall will be more easily dehydrated due to the treatment with alcohol that causes the size of the cell pores become smaller and the permeability is reduced so that the violet crystal dyes which are the main dyes cannot get out of the cell ${ }^{[8]}$.

Gram positive bacteria is a bacterium that retains violet crystal colour during gram-staining process so that it will be blue or purple under the microscope. On the other hand, gram-negative bacteria will be red or pink. 
Table 2. Results Identification of Lactic Acid Bacteria from Acar macroscopically

\begin{tabular}{cll}
\hline Isolate & Colony morphology & $\begin{array}{c}\text { Colony } \\
\text { figure }\end{array}$ \\
\hline Code & Shape: round & \\
& The edge: slippery & \\
& Elevasi: flat \\
& Colour: milk white \\
& Size: midle \\
& \\
\hline
\end{tabular}

Microscopic identification is done by gram staining. The growth temperature range for lactic acid bacteria is usually $15^{\circ} \mathrm{C}-45^{\circ} \mathrm{C}$. While the optimum of lactic acid bacteria for the growth is $30^{\circ} \mathrm{C}-37^{\circ} \mathrm{C}{ }^{[9]}$. Observations were made by looking at the morphology of the cell and the color of the isolate cells from each isolate.

\section{CONCLUSION}

Lactic acid bacteria obtained from isolation in a pickle totaled 9 isolates. Morphology of the sample colony in the form of bacillus with a circular colony, milk-white in color, is gram-positive The nature of pickled isolates is negative catalase, positive fermentation. And it was classified as Lactid acid bacteria.

\section{REFERENCES}

[1] Isolation and Characterization of Lactic Acid Bacteria (Lactobacillus sp) from Strawberry ( Fragaria vesca ). Proceedings of the Icomset International Seminar. https://iopscience.iop.org/issue/1742-6596/1317/1.

[2] Sari, Yuni et al. 2013. Isolation, Characterization and Identification of Lactic Acid Bacteria DNA (BAL) which has the potential as an antimicrobial from Yellow Passion Fruit fermentation. Journal of Chemistry at Andalas University Vol.2 No.2.

[3] Zahro Fatimatuz. 2014. Isolation and Identification of Lactic Acid Bacteria from Purple Passion Fruit

\subsubsection{Catalase Test}

The function of the catalase test in coccus shaped bacteria is to distinguish between positive catalase and negative catalse. The catalase test results on pickles are negative, because no gas bubbles are formed. Most bacteria produce catalase enzymes that can break down $\mathrm{H} 2 \mathrm{O} 2$ into $\mathrm{H} 2 \mathrm{O}$ and $\mathrm{O} 2$. Catalase is thought to be important for aerobic growth because $\mathrm{H} 2 \mathrm{O} 2$ is formed by the help of various respiratory enzymes that are toxic to microbial cells. Some bacteria that include negative catalase are Streptococcus, Leuconostoc, Lactobacillus, and Clostridium. The negative catalase bacteria do not produce bubbles. This means that $\mathrm{H} 2 \mathrm{O} 2$ given is not broken down by negative catalase bacteria, for example, Lactobacillus so it does not produce oxygen. The negative catalase bacterium does not have the catalase enzyme that describes $\mathrm{H} 2 \mathrm{O} 2$.

Fermentation as a producer of exopolysaccharide, Department of Biology, Faculty of Science and Technology, University of Maulana Malik Ibrahim Malang.

[4] Fevria, Resti. Hartanto, I. 2018 Isolation and Characterization of Lactic Acid Bacteria (Lactobacillus sp) from Tomato. EJurnal.UNP.Biosience.

[5] Fevria, Resti. Hartanto, I. 2019 Isolation and Characterization of Lactic Acid Bacteria (Lactobacillus sp) from Sauerkraut with the addition of Cayenne Pepper. E-Jurnal.UNP.Biosience.

[6] Usmiati, S. 2012 Development of Curd as Food. Agricultural Research and Development News 34 (2): $12-14$

[7] Pelczar, MJ, and ECS Chan. 1986. Basic Fundamentals of Microbiology 2. Translated by Hadioetomo RS, Imas T, Tjitrosomo SS, Figures SL. Jakarta: University of Indonesia Publishers. things: 489-522. 